\title{
sciendo
}

10.2478/jlecol-2020-0002

Journal of Landscape Ecology (2020), Vol: 13 / No. 1.

\section{THE ROLE OF CUSTOMARY LAW IN THE FOREST PRESERVATION IN BALI}

\author{
I NENGAH LESTAWI ${ }^{1}$ AND DEWI BUNGA ${ }^{2}$ \\ ${ }^{1}$ Lecturer of Social Science, Institut Hindu Dharma Negeri Denpasar, Indonesia, \\ Tel.: +361226656 \\ ${ }^{2}$ Lecturer of Law, Institut Hindu Dharma Negeri Denpasar, Indonesia \\ *Corresponding author e-mail: lestawi@ihdn.ac.id (Lestawi), bunga8287@gmail.com \\ (Bunga).
}

Received: $12^{\text {th }}$ October 2019, Accepted: $14^{\text {th }}$ December 2019

\begin{abstract}
The endeavors to preserve the forest in Bali cannot be isolated from the existence of local wisdom. Customary law, as a decision of Hindu religious leaders in Bali, is one of the local wisdoms which has been maintained by the society. This study examined the values of local wisdom held by indigenous people and reviewed the preservation of forests from a Hindu perspective. This research was conducted in three villages in Bali, namely Tenganan Village, Manggis Sari Village, and Sangeh Village. The residents of these villages believed that forest is a sacred area which must be maintained and preserved properly.
\end{abstract}

Keywords: environmental preservation; local wisdom; hindu; balinese villages; ethnology

\section{INTRODUCTION}

Forest sustainability is human responsibility. "Deforestation is a major global concern" (Payn et. al., 2015). Every year, the reduction in peatland forests cause the release of more than two billion tonnes of carbon. Forest functions are like a sponge and foam which absorb carbon dioxide in the air. Forest degradation will trigger the acceleration of global warming, therefore environmental sustainability is a major policy issue in every country that is carried out in various approaches. The center of this climate change discussion lies on the function of forests, particularly tropical forests in segregating carbon (Sujarwo, 2016). Although global warming is considered as the most alarming environmental issue on a global scale, environmental sustainability remains a multifaceted concern (Hadjikakou et. al., 2013).

Both scientific and local communities increasingly expect multiple values to be incorporated within planning for conservation and environmental management. (Raymonda et. al., 2009). In the Ecosophy theory, the environment is not merely a science but wisdom, a way of life, a pattern of life in harmony with nature. Wisdom governs life in harmony with nature as a household in a broad sense (Keraf, 2010: 95). Therefore, efforts to preserve forests require the role of local communities by exploring the traditional knowledge that they have.

Employing local wisdom held by indigenous people may be one of the strategies to preserve the environment and prevent deforestation (Achard, 2002). Nowadays, there is a growing awareness of the study of local wisdom in supporting the development of the 
nation. Local wisdom is a view of life, science, and various life strategies in the form of activities carried out by the local community to respond to numerous problems in sufficing their needs. In addition, local wisdom can further be interpreted as a system in the social, political, cultural, economic, and environmental order that exists in local communities. Typical characters that are inherent in local wisdom are dynamic, sustainable, and bound in communities.

Indigenous people have traditional knowledge in preserving the environment, including forests. Traditional ecological knowledge includes knowledge, practices, and beliefs that are more or less integrated with one another (Charnley et. al., 2007). Indigenous people understand the local history of forest purity; hence, they will preserve forests (Hull et. al., 2001). The beliefs of the local community are evaluated by religious and community leaders and then subsequently formulated into customary law that is applicable to local communities.

Bali (one of the islands that becomes a province in Indonesia) as an area that is famous for its customs and culture, still holds firm to some local wisdom as a philosophical ground to behave. Local wisdom has a potential to develop the unique characteristic and cultural image of Bali. In addition, Bali's diverse social systems and local wisdom may be regarded as its intellectual and cultural wealth which become part of the cultural heritage that needs to be preserved.

In preserving the environment, there is local wisdom that exists in Balinese society; such local wisdom is in the form of customary law which derives from written speeches and decisions of the religious leaders held by Parisadha Hindu Darma Indonesia. These written speeches and decisions are still held firmly by local people and believed to have binding power both in real and metaphysical ways that can affect their psychology. The situation is inherent with the religion adopted by the majority of the population in Bali, namely Hinduism.

In addition to the enforcement of national regulations, the preservation of forest in Bali is carried out by utilizing local wisdom approaches. Forest preservation consists of protection to flora and fauna, deployment of forest rangers and conducting observations. The aims of forest protection are to secure forest, forest land, and its environment in order to create sustainable and optimal utilization of the forest e.g. protection, conservation, and production.

"Forest management" is correlated to purposes defined by the landowner or responsible management entity, and there is typically particular management practice that maintains the defined goals (Birdsey \& Pan, 2015). Through a written decision to preserve the forest, it points out that forest conservation management strives to maintain the sacredness of the forest that is remarkably respected by the Hindu community in Bali. Having regard to this phenomenon, customary law in terms of preservation of the environment is particularly valuable for the Balinese, hence, it is imperative to conduct further study on its role in society. This study addressed the protection of forests from the Hindu perspective that is observed in several traditional villages in Bali and their implications for conservation of forest and environment.

The main focus of this study was to explore the relationship between forest conservation obligations and the teachings of Hinduism. In this case, the researchers examined several Hindu scriptures which contained the sanctity of the forest in the view of Hinduism and the philosophical consideration of human responsibility to conserve the forest. Religious law can only be applied if it has been formulated into customary law. Therefore, the researchers also examined several customary laws in Bali which contained provisions regarding forest conservation. 


\section{METHODOLOGY}

This study was conducted in three locations namely Tenganan Village, Manggis Sari Village, and Sangeh Village (Fig. 1). Tenganan Village is located in Manggis Sub-District, Karangasem Regency, Bali Province, Indonesia. Tenganan Village is an ancient Balinese village that still maintains the traditions of its ancestors. Manggis Village is located in the same Sub-District as Tenganan Village. Manggis Village cannot be regarded as an ancient Balinese village, as it has obtained much external influence. Sangeh village is located in Abiansemal Sub-District, Badung Regency, Bali Province, Indonesia. Sangeh Village is a tourist attraction in Bali and it also functions as a conservation area for monkeys. The three villages are villages that have forests in Bali, Indonesia.

Data collection was conducted through interviews with local community leaders and through the study of literature on Hindu scriptures which examined forest protection, customary law, and other scientific publications. Data analysis was carried out qualitatively.

\section{Fig. 1: Research Area Map}

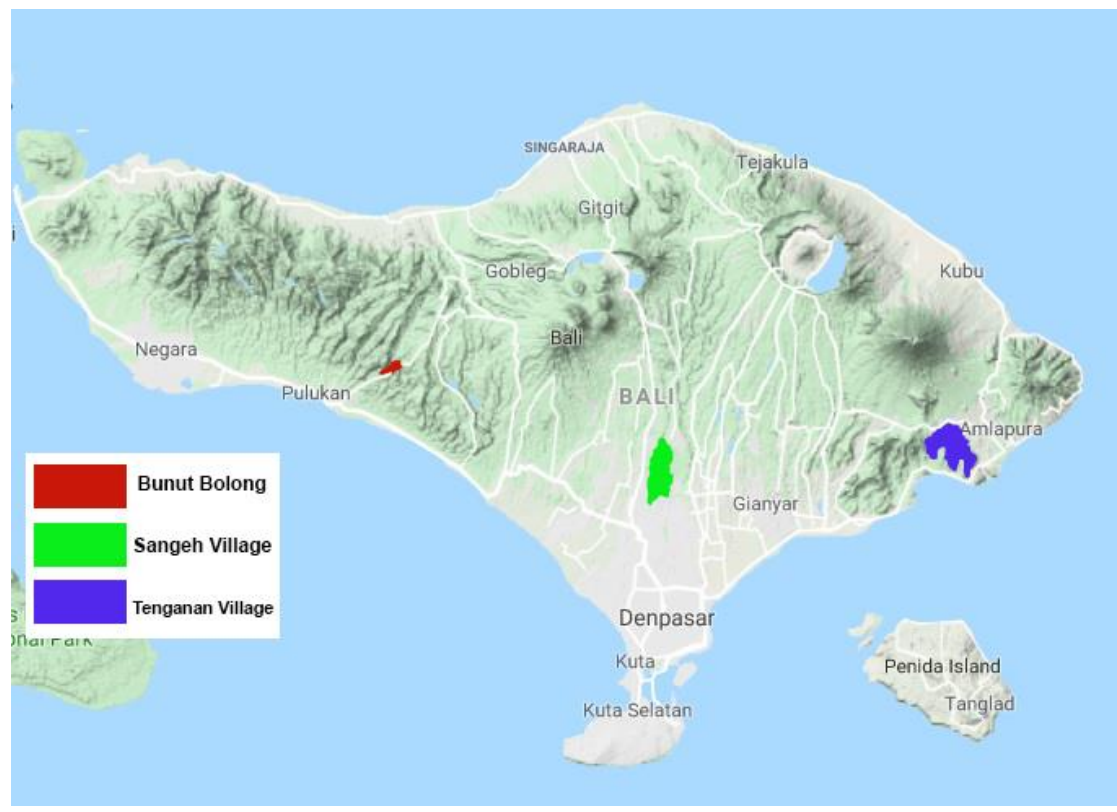

\section{RESULT AND DISCUSSION}

\section{Forest Preservation in the Perspective of Legal Pluralism}

Historically, legal pluralism in Indonesia was born from a diversity of cultures, ethnicities, religions, and races. Legal pluralism, one of the chief outgrowth of the anthropology of law, began with the recognition of customary law by the "centralist" law of the state, particularly the colonial state and post-independence successors states (Lubin, 2015). In the era of regional autonomy, legal pluralism has shifted more directly articulated within the state legal system because of the revival of customary and religious sources of importance (Wardana, 2014).

Bali as one of the provinces in the Unitary State of the Republic of Indonesia is subject to national law, namely a written law made by a legitimate state body. In addition, for certain 
legal fields such as land law, marriage law, environmental law, and inheritance law, the legal system in Indonesia also applies religious and customary law. Religious law can be applied directly as a binding legal rule (such as Islamic law) or can be perceived in customary law (other than Islamic law).

Based on data from the Central Bureau of Statistics, most of the population in Bali Province $(83.46 \%)$ adhere to Hinduism (BPS, 2018). Consequently, their actions are heavily influenced by their religious belief, namely Hinduism. In Hinduism, there exists a Hindu law deriving from Hindu scriptures which provides guidelines to behave for Hindus in the society. In reality, Hindu law can be imposed on the society through an institution formed by the society. Hindu law may be recognized in values held by society and the formulations of customary law; it even becomes a source of national law (Lestawi, 2015).

The Balinese consider that peace is attainable only when people respect the three harmonious connections that are identified as the Tri Hita Karana doctrine (Hakim et. al., 2009). The life of indigenous people in Bali is based on the Hindu philosophy of Tri Hita Karana (Roth \& Sedana, 2015). 'Tri' means three, 'hita' means happiness, prosperity, and 'karana' means a cause. So, 'tri hita karana' is three causes of human welfare or happiness so that humans live in balance. It consists of balances of human relations with God (perayangan), human relations with humans (pawongan), human relations with nature (palemahan).

Efforts to conserve forests are regarded as an obligation to create a harmonious relationship between humans and nature. Forests are regarded by indigenous people as sacred areas that must be preserved. In Hindu philosophy, the principle of forest protection can be identified in a number of scriptures. One of them is in the Holy Bible Rg. Veda III.51.5 which mentions: "Indraa ya dyaava osadhir uta aapah. Rayim raksanti jiyaro vanani" which means that without being protected by natural resources, human beings will never get a safe and peaceful life.

The belief to preserve forests continuously is also an order contained in Hindu scriptures. "The myth of Kalpavriksh - the tree that can grant all of one's wishes - signifies that ancient Hindus marked trees as the source of all affluence; their communities developed and flourished only amidst groves of trees. Not merely material affluence, but even the ultimate spiritual reward of moksha (salvation) is attained in the forest, the traditional retreat of rishis (sages) in search of truth. To worship trees, then, is to directly commune with God who is embodied in all Creation" (Baviskar, 1999).

Hindus in Bali are very courteous of the existence of trees and environmental sustainability. their respect upon trees is sincere devotion, aimed at Lord Vishnu and Goddes Wasundari. In mythology, Linggod Bhawa mentioned that Lord Vishnu as the God of Water transformed into a black pig looking for the lower end of the lingga yoni. In this search, Lord Vishnu met and married Goddes Wasundari (motherland). From this marriage, Bhoma was born (Sanskrit from trees). This illustrates natural events where water meets the earth (pertiwi) and gives birth to trees (Suardana, 2011).

The Hindu community in Bali also realizes quite well that the plants found in nature are divided into sacred and profane plants. Sacred plants cannot be cut down, they can barely be cut after performing religious rituals. Sacred trees that cannot be cut are allowed to grow. Around the area of the tree, there are offerings presented by the community. This tangible manifestation of respect can be seen from the existence of the tumpek uduh ceremony held every wuku wariga. Tumpek uduh is interpreted as the day of the descent of Sanghyang Sangkara which protects the life of all plants (trees) to thrive, avoid pests, and provide better and more abundant results. Even on the road, trees often circled with black and white cloth. This feature has a high philosophical meaning in which may be translated as the ancestors' 
guide to "humanize the environment" so that the trees will be treated like humans. Humans are expected to not cutting down the trees, but if it is forced to do it is expected that every falling tree is always followed by planting another tree. This tradition is still maintained as well (Suardana, 2011).

In the Hinduism teachings, there is great teaching declared as the law of Karma Phala or the law of cause and effect. It means that good deeds will present good things, while bad deeds will also be bad for humans. Associated to the concept of environmental safeguards, Hindu communities in Bali believe that if we take a good care of nature, it will take a good care of us in return, on the contrary, if we destroy it, we will get disaster.

Hindu law is fundamentally not a binding law (in the sense of addressing sanctions). Hindu law is only a moral understanding and life guidance to become a better human being. To be able to apply it in the community and provide sanctions for violations, Hindu Law must be formulated into customary law. "The communities included in the participatory mapping program in Bali experience a set of highly structured local institutions, approved by powerful, religiously legitimated customary traditions (adat). These institutions apparently present a strong basis for joint planning and implementation of decision-making" (Warren, 2005). "Such a customary law does, in fact, comprise of ethical and moral prescriptions on what is deemed proper behavior in dealing or using whatever resources are bestowed onto the community by the village forebears and local ancestral deities "(Samadhi, 2004).

In Hindu society in Bali, the recognition of forest preservation as regulated in various Hindu scriptures is formulated in the form of awig-awig. Awig-awig is a law that regulates the activities of the villagers. Awareness is binding on rights and obligations (Arnawa et.al, 2018). Awig-awig which applies to one traditional village (pakraman) is customarily not the same as awig-awig which applies in other traditional villages (Windia, 2010). The existence of awig-awig in a village is highly adhered to by the local indigenous people. When it compared with national law, indigenous people are more afraid to violate the awig-awig. This condition is caused by the sanctions provided by customary law concerning social sanctions involving the reputation and rights as well as obligations of a person as a member of indigenous people.

The adat revival was substantially backed by the indigenous and environmental international movements, then, it is an essential part of the background to the adat revival (Henley \& Jamie, 2008). Regulations regarding the obligations of indigenous people to preserve the environment under the customary law was intended to provide customary sanctions to the people who breach the rule.

In the teachings of Hinduism, endeavors to preserve forests and plants are human obligations to maintain good relations with nature. Forests are sacred areas, while plants and soils are considered as melting things that are not good. Therefore, its sustainability must be maintained. To respect the sanctity of forests and plants, Hindu communities in Bali carry out various religious rituals.

\section{The Customary Law in Forest Conservation}

\section{The Role of Customary Law in Forest Conservation in Tenganan Village}

Balinese people consider that preserving nature is a religious commitment which is translated into their customary law. "They keep their traditional early Balinese Austronesian lifestyle, with relatively free access to natural resources according to their traditional law" (Caneva et. al., 2017). They also strongly believe in the orders of religious leaders which serves as behavioral guidelines. The customary law in Tenganan Village significantly influences society's way of life. One of them is linked to the extraction of natural resources. 
Not all trees in Tenganan Village can be cut down, particularly jackfruit, candlenut, cempaka, tehep, pangi, and durian trees although such trees present in privately owned land. In mythology, the existence of forest in Tenganan Village was influenced by mythology regarding two forest-guardians snakes. There is a folklore which narrates that those two guardian snakes would chase anyone who damages the forest. A prevailing written local law that binds the society further enforces such folklore. Thus, it demonstrates that forest conservation has been embedded in local's belief.

According to Jro Mangku Widia, Tenganan village was burned in 1841. All the relics including the piece of writings made on Borassus flabellifer leaves containing this regulation at that time were burned. There was an effort to rewrite such piece of writings which was carried out according to the memories of the whole community and it was completed in 1842 . Since its establishment, then experiencing a fire, and then the rewriting phase, the residents of Tenganan Village had fully aware of the importance of the three elements which are inseparable, namely human, environment, and God. This awareness keeps Tenganan traditional village as it is today. It still has its green hill, organized housing areas and the society can perform religious activities in accordance with tradition and live a harmonious life (Interviewed on August 12 ${ }^{\text {th }}, 2016$ ).

Tenganan Traditional village is located in the valley between the hills (Fig. 2) which makes it susceptible to natural disasters. Therefore, there is a sustainable measure to keep the hills green. Residential areas are intentionally made in stages to avoid the erosion of water, and the building structure with north-south direction extends to avoid disasters. For the people of Tenganan village, the forest is a green garden land with trees. Such plantation forest consists of plants of economic value such as jackfruit, candlenut, Cempaka, durian, palm, and many other types of trees. The utilization of plantation forest products is regulated by customary regulations. Hence, in addition to its regular environmental function, it also has a social function. The customary rules regarding the use of the environment in Tenganan village are as follows:

1) The community is not allowed to cut down trees as their will and not to cut down living trees. If they violate these regulations, they are subject to sanctions in the form of monetary fines of 400 traditional coins (kepeng) and the harvested products would be confiscated by the community.

2) Trees may be cut down for building purposes or for firewood only after the tree dies.

3) Before a dead tree is being cut, a member of the society shall report it to the village leader, who will then verify the truth.

4) Types of trees that are forbidden to cut, for example, candlenut, tehep, durian, cempaka, palm, pangi, and jackfruit. The trees are prohibited from being cut down if they are still alive.

5) For certain reasons, for example, because they prevent the growth of the other trees, or the distance is too close to other trees, the prohibited trees may be cut down after obtaining permission from the community.

6) Trees may be cut for housing materials for newly married families.

7) This is called tumapiing, that logging can be done with the approval of the traditional village.

8) Logging of trees for village's needs such as to repair temples may be done after obtaining and consent of the traditional village residents regardless of the condition of the plants and their ownership.

9) Fruits cannot be picked from the tree. They can only be taken if they have fallen from the tree. This applies both to fruit trees located in private land and in village 
land. Those who violate this rule will be charged a fine of $25 \mathrm{~kg}$ of rice, plus the price of the fruit picked. $50 \%$ of the fine will be handed over to the adat village, and the other $50 \%$ will be given to the reporter whose identity is kept confidential.

10) Village communities may not sell/pawn land to residents outside the village. In case of violation of such rule, the traditional village will confiscate the said land.

Fig. 2: Tenganan Traditional Village

Source: Researchers' Documentation

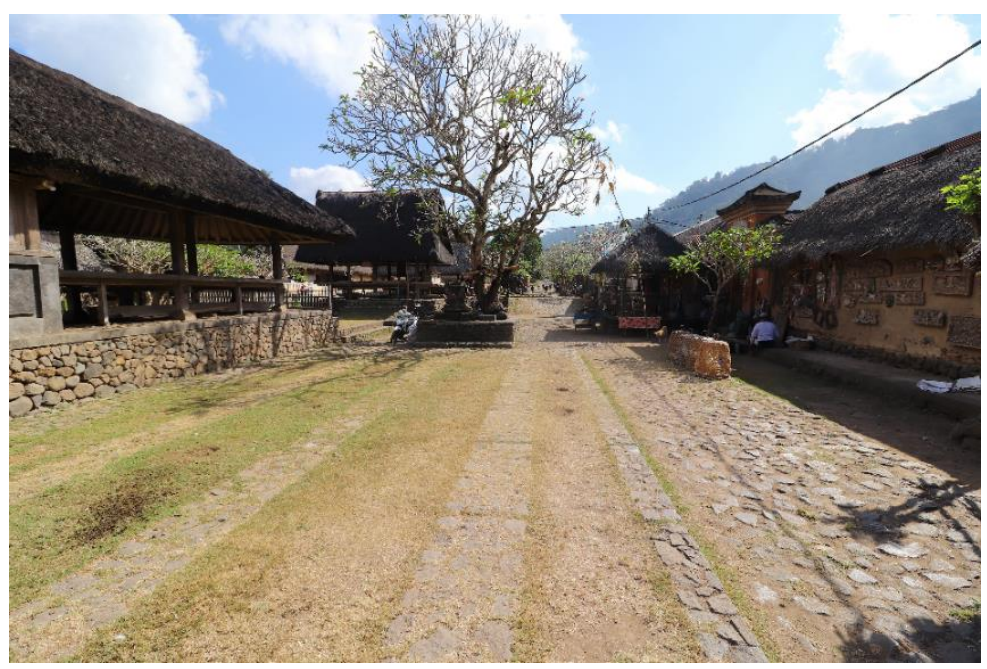

Fig. 3: Forest Gardens and Protected Sacred Areas

Source: Researchers' Documentation in 2016

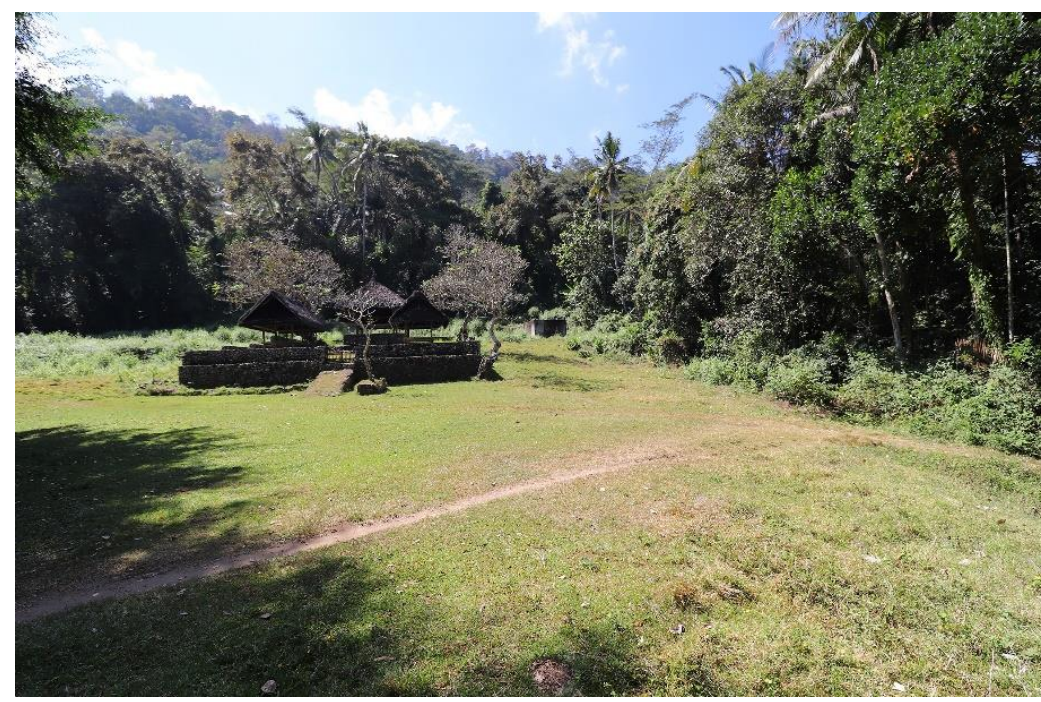

The existence of the environmental regulation which is highly adhered to by its citizens will maintain the ability of nature to support the life. This rule is consistent with the concept 
of environmental support capacity. In addition to the rules regarding forest utilization, it also regulates land ownership. As stated above, the area of plantation forests is 583,035 Ha. The ownership of the plantation forest is classified into private property covering an area of 432,060 Ha, temple land of 83,293 Ha, village-owned area of 46,545 Ha and community group owned area of 21,137 Ha. Even though it is private property, the land in Tenganan Village cannot be traded to outsiders (Putu Yudiana, Interviewed on August 12 ${ }^{\text {th }}, 2016$ ).

Based on the aforementioned information, a vast area of the plantations forest is preserved since such preservation includes private property, temple land, and land that belonged to the community groups. Fig. 3 depicts the preserved plantation forest in Tenganan village.

\section{The Role of Customary Law in the Conservation of Bunut Trees in Manggis Sari Village}

People have long appreciated that a robust management practice is required to maintain "the production and protection functions of forests" (MacDicken et. al., 2015). Indigenous people including those in Manggis Village, Karangasem District, Bali, Indonesia poses local wisdom to utilize natural resources provided by the forest and preserving forests, including indigenous people.

According to Wayan Dana (Traditional Chief of Manggis Village), Bunut Bolong is located in Manggis Sari Village, Pekutatan Sub-District, $49 \mathrm{~km}$ to the east of the city of Negara and approximately $86 \mathrm{~km}$ to the west of Denpasar City, Bali, Indonesia. Bunut Bolong is a Bunut tree that grows sustainably where in the middle of its roots lies a highway that connects Pekutatan Sub-District and Buleleng District. Bunut Bolong is a twiggy tree that grows right on the asphalt road and it can grow quite large (interviewed on September $\left.12^{\text {th }}, 2016\right)$. The name "Bunut" is a gift from the local community to refer to a plant species that has the characteristics of a Banyan tree.

In this tree area, there is also Pujangga Sakti Temple. This temple was built to honor a saint named Mpu Dang Hyang Sidhi Mantra. This temple was used by village elders in 1928 as a place to meditate asking for guidance on their problems, as at that time, there were a number of people affected by lethal diseases. It was believed that they obtained a sign to move the residential place which was located in the northern part of the Bunut Bolong tree to the south side of Bunut Bolong. Miraculously, such lethal disease was finally subsided. Because of that movement, then the local community believed that the mysterious tree had a strong magical power so that it continues to be preserved.

This Bunut tree has its own uniqueness. It has a hole which is as wide as an asphalt road in the middle of it which allows large vehicle such as bus and truk to pass through it. This Bunut Tree is said to have existed before the Dutch colonization, but not many people aware of its presence as it grew in the middle of the forest. It was only since the Japanese colonization, Bunut Tree was known to many people because of the Japanese at that time-built road access from Jembarana Regency to Pupuan Sub-District. At the time of the building of the road, the Japanese faced difficulties in trying to cut down the tree because every time they tried to cut it down they failed. Finally, the Japanese decided not to cut it but still built the road between the roots of the large Bunut tree.

The local people have long believed that the Bunut Tree was haunted, hence, they respect its presence. They are also convinced that the Bunut tree was a highly sacred place and no one threatens to cut down the tree. They even believe that if they take care of the Bunut tree and are regularly perform rituals there, the people around the area of Bunut Tree will be granted with wealth through abundant harvests and prevention of calamity. This phenomenon indicates a metaphysical belief which demonstrates a causal relation, thus giving rise to a belief that encourages people to comply with such rule and no one threatens to breach it; as they believe that a disaster would follow when it is done. 
According to Jero Mangku Gusti Tampi, the religious leader in Manggis Village, the community believed that the existence of Bunut Bolong in Manggis Village was a gift that was not arbitrary, both directly and indirectly affecting the life of the religious rituals in this village. People believe that if they do rituals regularly and take good care of them, the people will get prosperity in their agricultural commodities. For instance, clove farmers will get more than normal results and avoid crop failure, as well as coffee farmers, will get abundant yields. Conversely, if the community interferes with the existence of the Bunut Bolong, even to the point of daring to cut down its branches, then, of course, they will get distressed both for the logger and for the village manners. This belief has been around for a long time by the elders in Manggis Village. The ancestors had experienced a mass outbreak in the form of a deadly disease, but the community meditated in this place and then given physical assistance so that the village was moved to the south of the tree, and when the message is followed, the outbreak decreases (Interviewed on September $12^{\text {th }}, 2016$ ).

The people of Manggis Sari Village have written customary rules in preserving the sacred value or sustainability of this Bunut tree, namely:

1) The community is prohibited from cutting the twigs or roots of the Bunut tree without being preceded by Hindu rituals or ceremonies. If it is violated, the community has a firm belief that their village will suffer an epidemic which may disrupt the village safety.

2) The community is obliged to carry out a religious ritual every six months to maintain the sacredness of the Bunut Tree and as a form of gratefulness for it looking after the village.

3) People who want to take a trip across this tree is recommended to offer prayers to the shrine beside this tree to ask for the safety of their journey.

4) Villagers built a road next to a Bunut tree so that when there are large buses/vehicles passing by, they will not get caught in the tree hole and they do not damage the tree.

In addition, the community also believes that there are restrictions on brides not to pass the Bunut Bolong trees because if it is done, they believe the marriage will be canceled. They even avoid to carry corpses, coffins or carry out a ritual for the dead, hence, they build an alternative road beside the tree. This belief signifies how sacred this Bunut Tree is.

Based on these beliefs, until now, this Bunut Bolong Tree stands upright without ever being cut down or disturbed by the local community, so that this tree are still growing and soaring above the road which has cooled the surrounding area. The detail of Bunut Tree can be seen in the figure 4 below.

The conservation efforts of Bunut Bolong in Manggis Sari Village are based on a downward belief and then become the prevailing norm and are adhered to by the entire community. These norms that have been performed downwardly until now are still firmly believed and implemented. This shows that the norm has never undergone a change, both in written form and in the form of binding agreements. 


\section{Fig. 4: Bunut Bolong Tree as a Conserved Forest}

Source: Researchers' Documentation

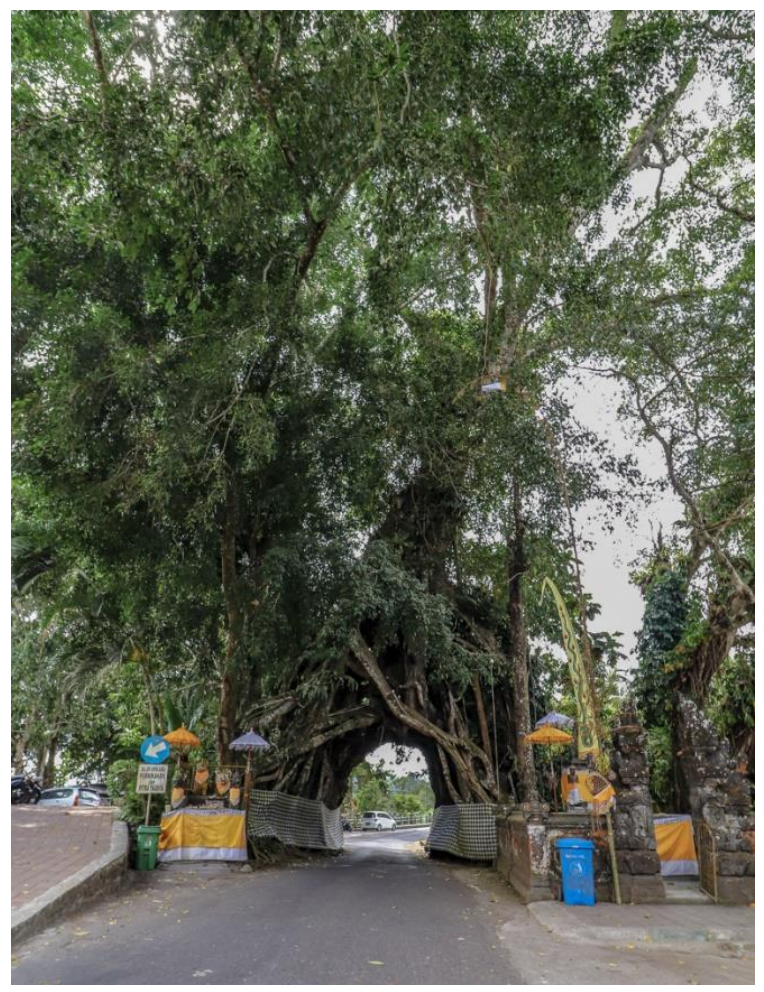

\section{The Role of Customary Law in the Conservation of Nutmeg Forest in Sangéh Village}

Based on the information from the local community leader (Bendesa Adat) of Sangeh Village, Ida Bagus Dipayana, the preservation of nutmeg and monkey forests (Sangéh forest tourism objects) has yet to be known certainly when it began. Based on the circulating folklore - as told by the Sangéh Traditional Village elders - this village emerged from the sound of the wind that awakened a shepherd from his sleep early in the morning. The sound of the wind was so strong as if it moved the trees from Mount Agung to Mengwi Village and stopped at the northern end of the Sangéh Traditional Village where the forest now exists. The narrative of the leader of Sangeh Village seems to be true. It is said that the area of Sangéh Village to the north, was an area of wilderness without inhabitants, but due to the growing number of the population, the forest was logged to allow the expansion of the settlement area. This is evidenced by the existence of an old forest or old-age forest that has never been entered by residents which are located in the east of the Sangéh traditional village (Interviewed on July $3^{\text {rd }}$, 2016).

According to Ida Bagus Sena and Ida Bagus Dipayana, there was a legend that narrated the existence of the Sangéh forest, temple, and monkeys in the forest. It was believed that the God who lived in Mount Agung had a daughter who committed wrongdoing, so she had to be punished in Pulaki Village. After being punished for so long, the daughter planned to return back to Mount Agung. The daughter's return was accompanied by several animals such as monkeys, snakes, and tigers. At some point, the princess rested to let go of fatigue. It was when she saw running forest. She then informed her followers "brothers and sisters, there is 
a running forest". The princess canceled her intention to return to Mount Agung. In the end, the princess settled in the forest, along with the animals she brought from Pulaki Village. Then, the Bukit Sari Temple was built in the middle of the forest to worship the princess. The legend can be traced today, the southern area of the forest is named the Siga Forest. The monkeys that inhabit the nutmeg forest (Fig. 5) are believed to be descended from monkeys carried by the princess. In addition, the people of Sangéh Village strongly believe in the existence of the Black Tiger and Yellow Tiger as nutmeg forest dwellers, but they only appear at special times during the ceremony at Pucak Sari Temple (Interviewed on July $3^{\text {rd }}$, 2016).

\section{Fig. 5: The monkeys that inhabit the nutmeg forest}

Source: Researchers' Documentation

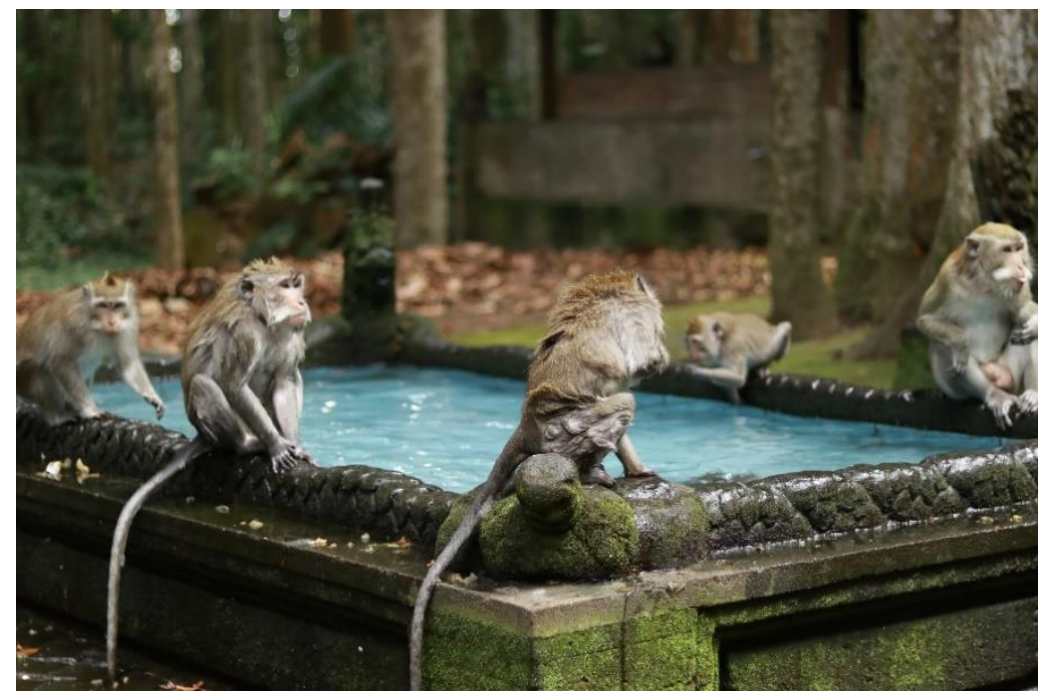

According to I Nyoman Subrata, a resident of Sangeh village, Raja Gusti Ketut Karangasem, the son of I Gusti Agung Made Agung namely Raja Mengwi who held the Blambangan Cokorda Sakti established a sacred area in the form of Pundak Sari Temple which is a present from the Almighty God in Beratan (Bedugul), Pucak Bon Tinggan, Batur, and Gunung Agung in the Seventeenth Century. This historical record adds to people's confidence in maintaining the nutmeg forest area because the forest is involved in the holy area of Pundak Sari Temple which is surrounded by the community of Sangeh Village (Interviewed on November $12^{\text {th }}, 2018$ ).

Another reason that prompted the community to make a great effort in preserving the forest is the community's belief of a spring found in Yeh Mumbul which is beneficial for the people of Sangéh Village for irrigation on agricultural land. Such spring was considered to have originated in the Sangéh Forest. Therefore, protection of the forest further means protection of the water which they need. The role of the Dutch East Indies Government which was later passed on by the Indonesian government cannot be ignored in strengthening the position of the Monkey Forest in Sangéh Village, namely through the establishment of the forest as protected forest, and it received a natural reserve status since 1919.

In 1973, Pakraman Village in Bali was reforming so that there was a standardization of Pakraman Village throughout Bali, this certainly had implications for the efforts of instructing carried out by the government at that time, particularly in terms of maintaining the 
uniqueness of the traditions without turning the standardization process. One of them is to explore local wisdom in terms of environmental preservation in every village in Bali, whether written in awig-awig or just a hereditary story. As performed in Sangeh Village, the Sangeh forest by the provincial government of Bali, at that time, was considered an extraordinary and invaluable asset, so it demanded to be safeguarded both in real and regulatory terms. This was stated by Ida Bagus Dipayana.

That the government has an investment in safeguarding Sangeh forests, notably in maintaining and strengthening the forest for the welfare of the village without having to destroy it. Accordingly, the government at that time routinely carried out training by replanting trees that had fallen, inviting the public to carry out the cleaning of plastic waste, including efforts to sustain the scarcity of monkey ecosystems by asking traditional villages to continually provide food for monkeys who live in the forest (Interview, November $16^{\text {th }}$, 2018).

In the interview, it was clear that the government constantly fostered the Sangeh village in terms of maintaining the local wisdom it possessed, primarily in protecting the Sangeh forests it owned. These efforts, in fact, are in line with the concept of Tri Hita Karana which is the philosophy of the people of Bali, that is, real efforts are conducted by preserving the forest environment, keeping harmony with others, establishing Parahyangan, and making the Sangeh forest a sacred area that must be preserved.

The same thing was also conveyed by I Nyoman Subrata, $\mathrm{SH}$ as follows:

That the government is perpetually willing to help the struggle to preserve the environment in the village, in addition to the written efforts (outlined in the Awig-awig). Real development efforts are also carried out such as planting trees, providing knowledge to the community concerning the importance of forests as a source of life, as well as the village once participated in the village competition at the provincial level in Bali. Of course in the race, the aspects of Parahyangan, Pawongan, and Pelemahan have continuously received guidance from the Badung Regency Cultural Service. In this development, it was received many inputs and practical tips in an effort to accomplish these three aspects (aspects of Parahyangan, Pawongan, and Pelemahan). Our villagers are very keen to attend to the importance of maintaining the balance of nature and safeguarding our proud forests (Interviewed on November $16^{\text {th }}, 2018$ ).

According to Ida Bagus Dipayana, a resident of Sangeh Village, the realization of harmonious relationship among Sangéh Traditional Village and the universe can be obviously seen from the existence of Sangéh forest tourism object as a potential asset in the Sangéh Traditional Village, which is always preserved by the Sangéh Village Traditional Village as a sacred area, because it is a pelaba (property/wealth) of Pura Bukit Sari. This forest impersonates a profoundly significant role for sustainable development in Sangéh Customary Village since the presence of the forest makes the Sangéh Traditional Village a tourist destination that is able to provide employment opportunities for its people so that the village economy can flow dynamically. Traditional villages receive income from entry and parking rates at Sangeh attractions. The local community also works as a tour guide, photographer, cleaning service, and other management activities (Interviewed on November $\left.12^{\text {th }}, 2018\right)$.

Moreover, the use of the forest as a tourism object strengthens the efforts of the local community to preserve its sustainability since they recognize that the sustainability of the Sangéh Monkey Forest equals to maintaining the sustainability of financial resources that are beneficial for Sangéh Village and its citizens. The written rules are called bhisama. Bhisama is a sort of fatwa, which is defined based on the decision of the paruman (meeting) of the 
sulinggih (religious leaders) which is held by the center of Parisadha Hindu Darma Indonesia (Association of Hindus in Indonesia). Bhisama applied in the forest conservation of Sangeh village, are:

1) The community is not allowed to cut down trees as their will and not to cut down trees which are still alive. This is because this forest is believed to be the source of the flow of water which is utilized by farmers to water their agricultural land.

2) For certain reasons, parts of this tree may be taken considering that the tree has died.

3) Logging of trees for village's needs such as to repair temples and be used for repairs to village halls may be carried out with consideration and approved by the whole community.

In an ecological perspective, the presence of this forest creates a cool climate in Sangéh Village and its surrounding areas. It also provides substantial benefits for the residents of Sangéh Village and the downstream communities who earn a living as farmers, because this forest created several springs that may be utilized as irrigation water for agricultural activities.

The following figure is the condition of forest in Sangeh Village.

\section{Fig. 6: Nutmeg Forest in Sangéh Village}

Source: Researchers' Documentation

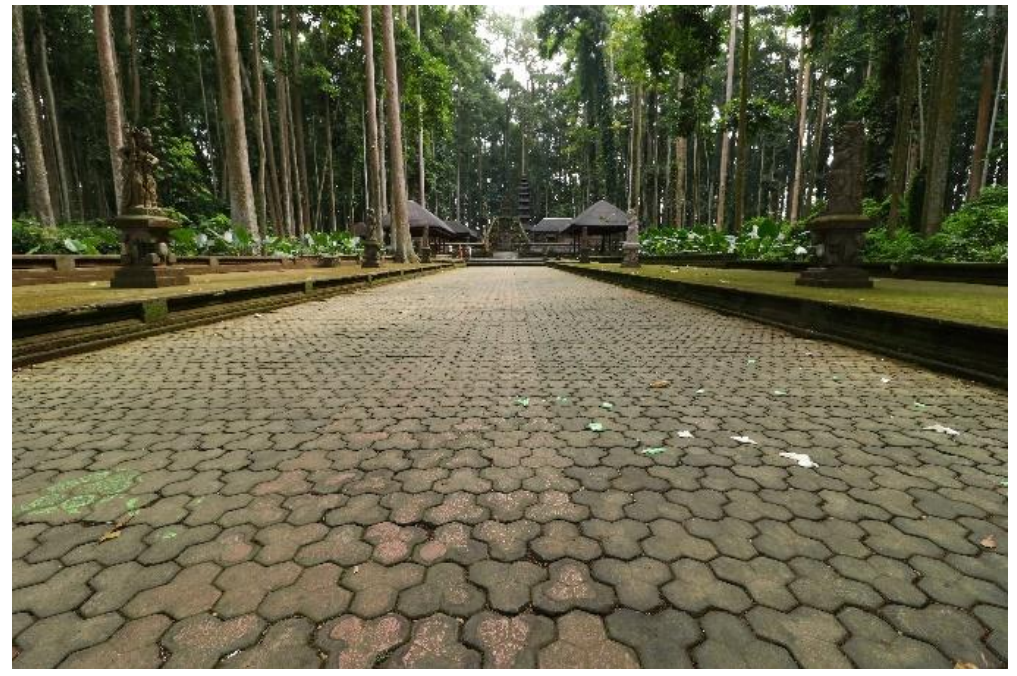

Communities in the Tenganan Village have customary rules about the use of the environment, such as a prohibition on buying and selling land, a ban on cutting trees except for certain purposes and a ban on picking fruit. Forest protection in the Tenganan Village is set forth in awig-awig (village regulations). The preservation of the Bunut Tree in Manggis Sari Village is carried out with the prohibition of cutting Bunut trees. The Mangosteen Traditional Village views the bunut tree area as a sacred area, so there is a prohibition for brides and corpses to pass through the area. Indigenous people also perform various rituals to respect the sanctity of the bunut tree. Preservation of nutmeg forest in Sangéh Village has been carried out since the Dutch Colonial era with the establishment of this area as a cultural 
heritage. The establishment of nutmeg forest as a tourist area is a synergy for indigenous people, governments, and tourists to preserve nutmeg forest.

\section{Conservation of forests by other indigenous peoples}

One strategy for protecting forests from deforestation is to develop local wisdom owned by indigenous peoples. This strategy is not only owned by indigenous peoples in Bali, but also indigenous peoples in various places, even in several countries. Efforts to protect forests carried out by indigenous peoples are influenced by culture, belief systems, and values adopted by local communities. Indigenous peoples protect forests because they feel that forests are part of their lives. The forest is seen as a sacred place and a source of life for the local community.

The indigenous people of Nanggro Aceh Darussalam (one of the provinces in Indonesia) take care of the forest by involving the Peutua Uteun (Commander of the Forest). The position of Peutua Uteun was lifted from the local wisdom established by the Aceh government based on qanun (a regional regulation sourced from Islamic law enforced in Aceh) that applies to protecting forests. All residents have a sense of responsibility in managing the forest in terms of pageu gampong. The community plays a role in reporting illegal logging practices, forest fires, wood theft that occurs in pockets of river basins (Azwir et. al., 2017).

Indigenous peoples in Bali and indigenous peoples in Nanggro Aceh Darussalam share responsibility for forest preservation. The Nanggro Aceh Darussalam Regional Government expressly regulates the synergy of the regional government with the community in preserving forests as stipulated in the qanun. This condition is different from the traditional communities in Bali where even though the obligation to conserve forests is regulated in formal regulations, the community still carries out the obligation to conserve forests based on its belief system.

The Kajang tribe is an ethnic group that lives in the interior of the eastern part of Bulukumba district, South Sulawesi, Indonesia. They uphold the teachings of their ancestors to harmonize life with nature so that they seem closed to the outside world. One of the teachings they hold firm is that Pari Ri Kajang is known for its messages about the balance of life. Pasang Ri Kajang is a message and the mandate of the ancestors of the Kajang tribe to protect nature, especially forests which are their source of life. The ancestral message reads "Jagai linoa lollong bonena kammayya tompa langika siagang jelua siagang boronga" which means Tide above means preserving the earth and its contents, as well as the sky, earth, humans and forests. The Kajang tribal community regarding the role of Ammatoa is a supervisor to prohibit logging by both parties within the community and outsiders who are trying to cut down trees (Abeng, 2019).

The Kajang customary community treats the forest as a source of life, so as a consequence, they have a moral obligation to preserve the forest. The effort to preserve the forest is believed by the community as the mandate of the ancestors that must be carried out by the next generation. The fundamental difference from forest conservation efforts between the Kajang tribe and indigenous peoples in Bali is in the system of social interaction. The Kajang people seem closed to the outside world. Unlike the indigenous people in Bali who despite preserving the forest with existing traditions, but also make the forest as a tourist destination. This condition certainly shows the openness of indigenous peoples in Bali with the outside world.

Research conducted by Ranjay K. Singh, Shah M. Hussain, T. Riba, Anshuman Singh, Egul Padung, Orik Rallen, YJ Lego and Ajay Kumar Bhardwaj on the Adi community of Arunachal Pradesh (Ar P) state in the Eastern Indian Himalayas shows that Adi community 
classifies forests based on ecological, social, cultural and apparent livelihood indicators based on traditional ecological knowledge. Community-owned forests are collectively managed by an indigenous institution 'Kebang' ((local village court). Conflicts relating to forest land use and resource management are resolved by the customary chief 'Gaon Burha' and his associates using traditional norms. various festivals for forest preservation and various other natural resource management (Singh et. al., 2018).

The efforts to protect the forests by the Adi community and indigenous peoples in Bali are similar. This can be understood because these two indigenous people are Hindus who are very close to ritual traditions. Adi community has a clear management and division of tasks in conserving forests, and even has law enforcement institutions at the level of indigenous peoples.

\section{CONCLUSION}

The social implications are, the customary law has a prominent role in forest preservation which is supported by the existence of customary law in each village in Bali. Moreover, the regional government has made efforts to revitalize the values of traditional villages through the formation and competition of traditional villages since 1973, so that they continue to perform their ecological function.

Environmental conservation efforts are not limited only to the forest environment. This effort is also carried out to the residential area by maintaining the authenticity and the nature of the residential area. It seems to be an effort from the community to maintain harmony with nature.

Any form of customary law carried out by Hindus has its own implications. Customary law carried out by the community is a manifestation of sincerity to the essence and religious values to demonstrate devotion to the Creator. The religious aspect is closely associated with the people's belief system towards God's omnipotence. This is because the role of customary law is constantly correlated with a belief that regulates every step and behavior of the community. As in several villages in Bali, the customary law in forest conservation results in the deterrence of people who want to commit an action which may damage the forest, as they believe it may negatively impact the perpetrator. This is linked to the role of customary law which is a belief of causal law, in which good deeds generate good results and vice versa.

\section{ACKNOWLEDGMENTS}

1. Institut Hindu Dharma Negeri Denpasar

2. The community in Tenganan Village, Manggis Sari Village, and Sangeh Village

\section{REFERENCES}

Abeng, A. T. (2019). The Role of Tidal Ri Kajang in the Culture of the Kajang Community, Bulukumba Regency (Ethnographic Study). Ecosystem, 19 (1), 54-60.

Achard, F., Eva, H. D., Stibig, H. J., Mayaux, P., Gallego, J., Richards, T., \& Malingreau, J. P. (2002). Determination of deforestation rates of the world's humid tropical forests. Science, 297(5583), 999-1002. DOI: 10.1126/science.1070656.

Arnawa, N., Gunartha, I. W., \& Sadwika, I. N. (2018). Balinese Hegemonic Politness in Awig-Awig of Desa Pakraman. Theory and Practice in Language Studies, 8(11), 1485-1493. 
DOI: http://dx.doi.org/10.17507/tpls.0811.13.

Azwir, A., Jalaluddin, J., \& Ibrahim, I. (2017). Peranan Masyarakat Dalam Menjaga Kelestarian Hutan Sebagai Sumber Kehidupan. Jurnal Ekonomi Manajemen dan Akuntansi (JEMSI), 3(1).

Baviskar, A. (1999). Vanishing Forests, Sacred Trees: A Hindu Perspective on Eco-Consciousness. Asian Geographer, 18(1-2), 21-31. DOI: https://doi.org/10.1080/ 10225706.1999.9684045.

Birdsey, R., \& Pan, Y. (2015). Trends in management of the world's forests and impacts on carbon stocks. Forest Ecology and Management, 355, 83-90. DOI: https://doi.org/ 10.1016/j.foreco.2015.04.031.

BPS. (2018). Penduduk Provinsi Bali Menurut Agama yang Dianut Hasil Sensus Penduduk 2010. Retrieved December 21, 2018, from https://bali.bps.go.id/statictable/2018/02 /15/33/penduduk-provinsi-bali-menurut-agama-yang-dianut-hasil-sensus-penduduk-2010.ht $\mathrm{ml}$.

Caneva, G., Traversetti, L., Sujarwo, W., \& Zuccarello, V. (2017). Sharing ethnobotanical knowledge in traditional villages: evidence of food and nutraceutical "core groups" in Bali, Indonesia. Economic botany, 71(4), 303-313. DOI: https://doi.org/10.1007/ s12231-017-9395-x.

Charnley, S., Fischer, A. P., \& Jones, E. T. (2007). Integrating traditional and local ecological knowledge into forest biodiversity conservation in the Pacific Northwest. Forest ecology and management, 246(1), 14-28. DOI: https://doi.org/10.1016/j.foreco.2007.03.047.

Hadjikakou, M., Chenoweth, J., \& Miller, G. (2013). Estimating the direct and indirect water use of tourism in the eastern Mediterranean. Journal of environmental management, 114, 548-556. DOI: https://doi.org/10.1016/j.jenvman.2012.11.002

Hakim, L., Kim, J. E., \& Hong, S. K. (2009). Cultural landscape and ecotourism in Bali Island, Indonesia. Journal of Ecology and environment, 32(1), 1-8. DOI: https://doi.org/10.5141/JEFB.2009.32.1.001.

Henley, D., \& Davidson, J. S. (2008). In the name of adat: regional perspectives on reform, tradition, and democracy in Indonesia. Modern Asian Studies, 42(4), 815-852. DOI: https://doi.org/10.1017/S0026749X07003083.

Hull, R. B., Robertson, D. P., \& Kendra, A. (2001). Public understandings of nature: A case study of local knowledge about" natural" forest conditions. Society \& Natural Resources, 14(4), 325-340. DOI:https://doi.org/10.1080/08941920118871

Lestawi, I Nengah. (2015). Hukum Hindu Suatu Perkembangannya. Surabaya: Paramita.

Lubin, T. (2015). Writing and the recognition of customary law in premodern India and Java. Journal of American Oriental Society, 135(2), 225-259. DOI: 10.7817/jameroriesoci. 135.2.225.

MacDicken, K. G., Sola, P., Hall, J. E., Sabogal, C., Tadoum, M., \& de Wasseige, C. (2015). Global progress toward sustainable forest management. Forest Ecology and Management, 352, 47-56. DOI: https://doi.org/10.1016/j.foreco.2015.02.005.

Payn, T., Carnus, J. M., Freer-Smith, P., Kimberley, M., Kollert, W., Liu, S., ... \& Wingfield, M. J. (2015). Changes in planted forests and future global implications. Forest Ecology and Management, 352, 57-67. DOI: https://doi.org/10.1016/j.foreco.2015.06.021.

Raymond, C. M., Bryan, B. A., MacDonald, D. H., Cast, A., Strathearn, S., Grandgirard, A., $\&$ Kalivas, T. (2009). Mapping community values for natural capital and ecosystem services. 
Ecological economics, 68(5), 1301-1315. DOI: https://doi.org/10.1016/j.ecolecon. 2008.12.006.

Roth, D., \& Sedana, G. (2015). Reframing Tri Hita Karana: From 'Balinese Culture'to Politics. The Asia Pacific Journal of Anthropology, 16(2), 157-175. DOI: https://doi.org/10.1080/14442213.2014.994674.

Samadhi, T. N. (2004). Man, culture and environments: an anthropological approach to determining the Balinese urban design unit. Journal of Urban Design, 9(2), 205-223. DOI: https://doi.org/10.1080/1357480042000227825.

Singh, RK, Hussain, SM, Riba, T., Singh, A., Padung, E., Rallen, O.,\& Bhardwaj, AK (2018). Classification and management of community forests in Indian Eastern Himalayas : implications on ecosystem services, conservation and livelihoods, Ecological Processes, 7 (1), 27.

Strunk Jr., W., White, E.B (2000) The Elements of Style, fourth ed. Longman, New York. Reference to a chapter in an edited book: Mettam, G.R., Adams, L.B., 2009. How to prepare an electronic version of your article, in: Jones, B.S., Smith , R.Z. (Eds.), Introduction to the Electronic Age (pp. 281-304), E-Publishing Inc., New York.

Suardana, I. W. (2011). Implementasi Prinsip Perlindungan Hutan dalam Penanggulangan Illegal Occupation di Kawasan Hutan (Studi Kasus pada Illegal Occupation di Tahura Ngurah Rai). Unpublished magister thesis, Program Magister Ilmu Hukum, Universitas Udayana, Denpasar.

Sujarwo, W. (2016). Stand biomass and carbon storage of bamboo forest in Penglipuran traditional village, Bali (Indonesia). Journal of forestry research, 27(4), 913-917. DOI: https://doi.org/10.1007/s11676-016-0227-0.

Wardana, A. (2014). Alliances and contestations in the legal production of space: The case of Bali. Asian Journal of Comparative Law, 9, 145-171. DOI: https://doi.org/10.1017/ S2194607800000958.

Warren, C. (2005). Community mapping, local planning and alternative land use strategies in Bali. Geografisk Tidsskrift-Danish Journal of Geography, 105(1), 29-41. DOI: https://doi.org/10.1080/00167223.2005.10649524.

Windia, W. P. (2010). Bali mawacara: kesatuan awig-awig, hukum, dan pemerintahan di Bali. Udayana University Press. 